Zabytkoznawstwo i Konserwatorstwo XLI, Toruń 2011

Anna Dzierżyc-Horniak

\title{
Ewolucja i współkształtowanie - zasada wzajemnej stymulacji między krytykami a artystami w Galerii Foksal (Programy Galerii w latach 1966-1981)*
}

$\mathrm{K}$

iedy w 1965 roku w kręgu młodych warszawskich krytyków sztuki - Wiesława Borowskiego, Anki Ptaszkowskiej, Mariusza Tchorka pojawił się projekt założenia galerii, nikt nie przypuszczał, że stanie się ona jedną z najważniejszych dla polskiej sztuki współczesnej. Przez kolejne lata Galeria Foksal była znaczącym podmiotem w dyskursie artystycznym. Wiele z realizacji przygotowanych w ramach i przez Galerię wskazywało nowe kierunki rozwoju sztuki w Polsce. Jednym ze źródeł tego „sukcesu” była niewątpliwie formuła działania instytucji, oparta na współpracy artystów i prowadzących na co dzień galerię krytyków sztuki. Toczone między nimi zmagania ideowe były niezwykle twórcze - dzięki zaś wzajemnej stymulacji wspólnie kształtowali oni zmieniające się oblicze Foksalu. Proces ten widać najwyraźniej w manifestach programowych z lat 1966-1981, których urzeczywistnieniem stały się konkretne działania artystyczne prowadzone w i poza przestrzenią galerii. Podjęta w niniejszym artykule analiza skupiać się będzie zatem na prześledzeniu, jak przez programy zmieniały się i wciąż na nowo były definiowane wzajemne relacje między artystami i krytykami Foksalu.

Zasada wzajemnej stymulacji artystów i krytyków obowiązywała od samego początku istnienia Galerii i stanowiła przez kolejne lata ważny - naturalny, nieodłączny i konstytutywny - element każdego po-

* Niniejszy tekst powstał na podstawie referatu autorki wygłoszonego podczas II Środkowoeuropejskiego Forum Doktorantów Historii Sztuki, UAM, 27-30 X 2005 r., Poznań. Tekst został przeredagowany i rozszerzony o nowe wątki z badań prowadzonych w kolejnych latach. 
dejmowanego działania. Początki tej współpracy sięgają połowy lat 50., kiedy to w Lublinie spotkały się drogi przyszłych krytyków - współzałożycieli galerii: Wiesława Borowskiego, Anki Ptaszkowskiej, Mariusza Tchorka. Studia na Katolickim Uniwersytecie Lubelskim ${ }^{1}$ rozpoczęły konsekwentny w swym rozwoju proces, którego etapami była ich działalność przy Grupie „Zamek” i współredagowanie pisma „Struktury”. Wtedy po raz pierwszy nastąpiło przenikanie się działalności artystów i krytyków. Grupa „Zamek”2 przebojem wdarła się na polskie (a później

1 Wiesław Borowski i Hanna Ptaszkowska skończyli historię sztuki na KUL-u. Wiesław Borowski tytuł magistra uzyskał 28 stycznia 1955 roku na podstawie pracy „Kościół i klasztor pokamedulski na Bielanach pod Warszawą”, w tym samym dniu zdał egzamin również Jerzy Ludwiński. Grupa „Zamek”. Historia - krytyka - sztuka, seria Sztuka Nowa. Źródła i komentarze, red. M. Kitowska-Łysiak, M. Lachowski, t. IV, Lublin 2007, s. 161. Hanna Ptaszkowska obroniła się 16 stycznia 1959 roku. Jej praca magisterska pt. „Monografia Tadeusza Kantora” nie spodobała się specjalizującemu się w baroku wileńskim i negatywnie nastawionemu do sztuki nowoczesnej jej promotorowi prof. Piotrowi Bohdziewiczowi, sytuację jako kopromotor dobrą oceną uratował jednak Jacek Woźniakowski. Grupa „Zamek”. Historia - krytyka - sztuka, s. 174. Szczególnie ważne dla kształtowania poglądów młodych entuzjastów sztuki nowoczesnej były wykłady z zakresu historii sztuki nowoczesnej i historii doktryn artystycznych prowadzone przez Jacka Woźniakowskiego, który pokazywał prawidłowości rozwoju plastyki nowoczesnej, ale przede wszystkim sprzyjał ich poszukiwaniom, rozbudzał zainteresowania artystyczne, pobudzał intelekt i wyobraźnię. O czasach w Lublinie wspominali w rozmowie m.in. J. Ludwiński, W. Borowski, H. Ptaszkowska, J. Woźniakowski, Wł. Borowski. O grupie "Zamek” i nie tylko. Z Włodzimierzem Borowskim rozmawia Anna Maria Leśniewska, „Kresy” 1996, nr 4(28), s. 211-216; Legenda bezinteresowności. Z Jackiem Woźniakowskim rozmawia Magdalena Ujma, "Kresy” 1996, nr 4(28), s. 190-193; Takie zwariowane czasy. Z Jerzym Ludwińskim rozmawia Magdalena Ujma, „Kresy” 1996, nr 4(28), s. 197-203; Pobocza. Z Hanna Ptaszkowska rozmawia Agnieszka Czyżewska, „Kresy” 1996, nr 4(28), s. 194-196; Między Lublinem a Warszawa. Z Wiesławem Borowski rozmawia Anna Baranowa, „Odra” 2005, nr 9, s. 61-62. Wszystkie rozmowy przedrukowane w: Grupa „Zamek”. Historia - krytyka - sztuka.

2 Grupa „Zamek” reprezentowana była przez m.in. takich artystów, jak: Włodzimierz Borowski, Tytus Dzieduszycki, Jan Ziemski i wielu innych. O Grupie „Zamek” pisali m.in. M. Głazowski, A. Rottenberg, Grupa Zamek, w: Polskie życie artystyczne, s. 39-43; L. Nader, Od Koła Młodych Plastyków do Grupy Zamek. Krótka historia, w: Grupa Zamek. Lublin 1956-1960. Doświadczenie struktur. Włodzimierz Borowski, Tytus Dzieduszycki, Jerzy Ludwiński, Jan Ziemsk. Włodzimierz Borowski. Metamorfozy, kat., red. M. Bauer, H. Jaśkiewicz, A. Miastkowski, 11 I-17 II 2002, Muzeum Sztuki, Łódź 2002, s. 95-102; Grupa „Zamek”. Historia - krytyka - sztuka. 
i paryskie ${ }^{3}$ ) salony wystawowe czasu odwilży. Jak pisała w Ankiecie lubelskiej Maria Bechczyc-Rudnicka: „trzeba przyznać obiektywnie: grupa "Zamek" posiada wielki atut w postaci związanych z nią uczuciowo młodych, zdolnych krytyków - »współwyznawców«, z entuzjastą nowej sztuki Jerzym Ludwińskim na czele"4. Owo zaprzyjaźnione grono krytyków, funkcjonujące obok składającej się formalnie tylko z plastyków, Grupy „Zamek” tworzyli również Anka Ptaszkowska i Wiesław Borowski, a później także Mariusz Tchorek. Gdy Grupa znajdowała się w punkcie szczytowym swego rozwoju artystycznego, z inicjatywy

3 Pierwsza wystawa Grupy „Zamek” otwarta została w miejscu wówczas szczególnym dla polskiej awangardy - w warszawskiej galerii „Krzywe Koło” w maju 1957 roku. J. Ludwiński, Wystawa Grupy „Zamek”, „Życie Literackie” nr 21 dod. „Plastyka” nr 2, s. 7. Rok później, we wrześniu po raz kolejny pokaz Grupy „Zamek” w tej samej galerii. Grupa „Zamek”, kat., [wstęp] J. Ludwiński, Galeria Sztuki Nowoczesnej Krzywe Koło, Warszawa 1958. W 1957 roku odbyła się też ich wystawa w klubie TPPR Przyjaźń w Białymstoku. W czerwcu tegoż roku na łamach „Kultura i Życie” ukazał się artykuł, w którym autorki prezentowały opinie znanych polskich plastyków o Grupie „Zamek”. M. May, H. Ptaszkowska, „Zamek” w opinii plastyków polskich, dod. „Kultura i Życie” 1957, nr 26 z dn. VI 30. W grudniu 1958 roku odbył się pokaz Grupy „Zamek” w Pałacu Sztuki w Krakowie. Grupa „Zamek”, kat., red. B. Heyduk, K. Hukarz, Pałac Sztuki, Kraków, XII 1958. Artyści Grupy „Zamek” uczestniczyli też w prestiżowej III Ogólnopolskiej Wystawie Sztuki Nowoczesnej w 1959 roku w warszawskiej Zachęcie. III Ogólnopolska Wystawa Sztuki Nowoczesnej, kat., CBWA Zachęta, Warszawa IX 1958 r. Obszerny wybór wypowiedzi krytyków na te temat III WSN oraz osobne omówienia wystawy autorstwa J. Boguckiego, W. Borowskiego, A. Paszkowskiej zamieściły „Struktury” - „Kamena” 1959, nr 19-20, dod. „Struktury” nr 6. W 1960 roku trzej najbardziej rozpoznawalni artyści grupy: Wł. Borowski, T. Dzieduszycki, J. Ziemski przedstawili swoje prace na dwóch wystawach w Paryżu - w Galerie de George Fall i Ranelaigh de Cinema. Wystawy cieszyły się dużym zainteresowaniem i pozytywnym oddźwiękiem, a jeden z krytyków francuskich użył stwierdzenia „cud polski”. J. C. Lambert, La miracle polonais, „France Observateur” 1960, nr 526, s. 10; E. Jaguer, L'avant-garde polonaise: structure et dynamisme, „Cahiers du Musée de poche” 1960, nr 4, s. 24; idem, La Face Inconnue de la Terre, "Phases” 1960 z dn. 5-6 I. W Polsce obszerna relacja zawierająca skróty z tekstów krytyków francuskich pojawiła się w „Życiu Literackim” - J. K., Le mircale polonais, „Życie Literackie” 1960, nr 36, s. 11. O przychylności paryskiej krytyki wobec propozycji polskich artystów ok. 1960 roku pisała też Anna Baranowa, Polski cud, w: Malarstwo materii 1957-1963. Warszawa - Lublin [folder wystawy], Galeria Zderzak, Kraków 2001, s. nlb. 3.

4 Wypowiedź Marii Bechczyc-Rudnickiej w Ankiecie lubelskiej pytającej na łamach "Struktur” o opinie na temat środowiska artystycznego Lublina - „Kamena” 1959, nr 13-14, dod. „Struktury” nr 3, s. 7. 
Ludwińskiego powstał przy lubelskiej „Kamenie” dodatek poświęcony sztuce współczesnej - „Struktury”. Pismo, w którego redagowanie zaangażowani byli Borowski i Ptaszkowska, stało się swoistym przedłużeniem od strony teoretycznej działalności artystów „Zamku”.

Kolejne etapy tego przenikania się działalności krytyków i artystów odnajdujemy już w Warszawie, gdzie po wyjeździe z Lublina (początek lat 60.) trafili przyszli współzałożyciele Foksalu. Borowski, Tchorek i Ptaszkowska nawiązali wtedy współpracę z Marianem Boguszem i jego Galerią Krzywego Koła. Jak wspominał po latach Borowski: „Bogusz był jednym z tych artystów, którzy zaszczepili nam entuzjazm do nowej sztuki na wiele lat. Zapraszał nas potem na półkonspiracyjne spotkania, dyskusje i pokazy malarstwa do prywatnych mieszkań, do pracowni artystów. Chodziliśmy wszędzie, do teatru Mirona Białoszewskiego na Tarczyńskiej, do Dłubaka, a wkrótce zostając tam przez kilka lat

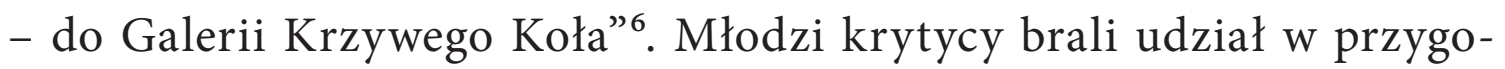
towywaniu wystaw, redagowaniu katalogów, rodzeniu się pomysłów i w ten sposób w praktyce doświadczali, jak należy prowadzić galerię sztuki. W galerii tej krytycy spotkali jednego ze swoich przyszłych "mentorów” - Henryka Stażewskiego, a także innych artystów tworzących kilka lat później środowisko Foksalu: Zbigniewa Gostomskiego, Edwarda Krasińskiego, Romana Owidzkiego. Można zatem za Stefanem Gierowskim powiedzieć, iż program Galerii Foksal zrodził się z doświadczeń Krzywego Koła, choć oczywiście ostatecznie sformułowany został kilka lat później ${ }^{7}$. Jak pisał Janusz Zagrodzki: „Foksal postawiła

5 Borowski z Ptaszkowską współtworzyli wraz z Jerzym Ludwińskim (redaktorem) w latach 1959-1961 pismo „Struktury”, dodatek plastyczny do lubelskiego pisma literackiego „Kameny”. Tchorek napisał do „Struktur” interesujący cykl artykułów. O „Strukturach” pisali m.in.: A. Wojciechowski, Lublin: grupa Zamek - „Struktury”, w: idem, Młode malarstwo polskie 1944-1974, Wrocław-Warszawa-Gdańsk 1975, s. 93-95; M. Derecki, Wśród plastyków. Środowisko Lubelskie, cz. 2, „Kamena” 1983, nr 25, s. 9; A. Rottenberg, Struktury, w: Polskie życie artystyczne w latach 1945-1960, red. A. Wojciechowski, Wrocław-Warszawa-Kraków 1992, s. 436-465.

6 W. Borowski, Wspomnienia o Marianie Boguszu, w: Galeria Krzywego Koła, kat., red. JanuszZagrodzki, Muzeum Narodowew Warszawie, VII-IX 1990, Warszawa 1990, s. 23.

7 W Krzywym Kole, rozmowa ze Stefanem Gierowskim przeprowadzona przez Janusza Zagrodzkiego w pracowni artysty w Warszawie, 20 września 1989 roku, w: Galeria Krzywego Koła, s. 46. 
na dość zdecydowaną koncepcję sztuki, dość jednorodną. Taka była potrzeba czasu i to musiało być realizowane w innym miejscu niż Krzywe Koło i przez innych ludzi"

Dzięki Ptaszkowskiej ${ }^{9}$ nawiązany został również kontakt z kolejnym ważnym artystą - Tadeuszem Kantorem. Kantor, poza całym swoim kapitałem teoretycznym, artystycznym i osobowościowym, mógł zaoferować krytykom jeszcze doświadczenia z organizowania krakowskich Krzysztoforów. Młodzi krytycy, skupieni teraz wokół charyzmatycznego Kantora i Stażewskiego, który był w środowisku artystycznym niekwestionowanym autorytetem, mogli zacząć wdrażać swój projekt Galerii. W 1965 roku idea nabrała realnego wymiaru - od Pracowni Sztuk Plastycznych przejęta została była zakładowa biblioteka, mieszcząca się przy ul. Foksal 1/4 w Warszawie w oficynie Pałacu Zamoyskich. I choć przestrzeń „Zdobycznego” lokalu była niewielka - składały się na nią tylko sala wystawiennicza o powierzchni $5 \times 7 \mathrm{~m}$ i dwa małe pokoje biurowe $^{10}$ - Galeria Foksal ${ }^{11}$ mogła już działać.

Pierwsze podejmowane działania pokazują, że w tworzeniu oblicza Galerii biorą wspólnie udział krytycy i artyści. Tak jest podczas pierwszej akcji Galerii, która odbyła się w kawiarni Towarzystwa Przyjaciół Sztuk Pięknych w Warszawie (10 XII 1965 roku), na pół roku przed premierową wystawą na Foksalu. Pod jej patronatem zrealizowany został happening Tadeusza Kantora Cricotage ${ }^{12}$ - jeden z pierwszych tego typu wydarzeń artystycznych w Polsce ${ }^{13}$. Oficjalnie Galeria zaczęła funkcjo-

8 Ibidem.

9 Przy pisaniu pracy magisterskiej, będącej monografią artysty, Hanna Ptaszkowska poznała i zaprzyjaźniła się z Tadeuszem Kantorem i Marią Stangret.

10 Wystrój Galerii prawie się nie zmienił, dziś wygląda ona tak samo jak przed laty. Obecnie w jednym z pokojów mieści się biuro galerii i jej archiwum, drugi stanowi malutki pokój biurowy.

11 Swoją nazwę Galeria przyjęła od nazwy ulicy, ta zaś od Ogrodu Foksalowego, założonego w połowie XVIII wieku. Był to ogród rozrywkowy dla szerokiej publiczności na wzór londyńskiego Vauxhallu (spolszczona nawa Foxhal) - T. Jaroszewski, Pałac Zamoyskich na Foksalu, Seria „Zabytki Warszawy”, Warszawa 1987, s. 12-13, 18, 78.

12 W. Borowski, Cricotage Tadeusza Kantora, „Kierunki” 1966, nr 1, s. 11; H. Ptaszkowska, Happening w Polsce (3), „Współczesność” 1969, nr 11, s. 8.

13 Warto zwrócić uwagę, że Tadeusz Kantor już 27 listopada 1964 roku razem z Kazimierzem Mikulskim i Marianem Warzechą aranżował wnętrze Galerii Krzysztofory dla siedmiogodzinnego koncertu Bogusława Schaeffera. Utwór Non 
nować od kwietnia 1966 roku, kiedy to miała miejsce pierwsza wystawa. We wstępie do katalogu wystawy pojawiły się deklaracje założycieli pokazujące, jakie znaczenie dla identyfikacji Galerii ma działalność artystów: „w organizowanych przez Galerię pokazach chcielibyśmy zwrócić uwagę szczególnie na dwa momenty. Po pierwsze - nie tyle demonstrować »dzieła sztuki« w ich »skończonej« postaci, ile ujawnić - warunki i sytuacje, które wiążą się z ich powstaniem. Po drugie - traktować te warunki i sytuacje jako organiczne elementy pokazu artystycznego. [...]. Wystawy wówczas - być może - stracą swój wtórny i neutralny wobec samego dzieła charakter i staną się formą aktywną artystycznie"14. Krytycy nie chcieli, aby ich galeria była tylko pośrednikiem między artystą a publicznością. Podobnie myśleli również artyści, którzy w Foksalu nie szukali tylko miejsca do zawieszania swoich obrazów i wystawiania rzeźb.

Te intuicje krytyków i poczynania artystów znalazły wyraz w tekście teoretycznym Wprowadzenie do ogólnej teorii Miejsca ${ }^{15}$, po raz pierwszy przedstawionym podczas I Sympozjum Artystów Plastyków i Naukowców w Puławach Sztuka w zmieniającym się świecie, w sierpniu $1966 \mathrm{roku}^{16}$. Tekst podpisany przez Borowskiego, Ptaszkowską i Tchorka miał charakter manifestu programowego Galerii Foksal. Autorzy manifestu, wychodząc od krytyki tradycyjnej wystawy i podważając tradycyjną rolę galerii, postulowali tworzenie miejsc tożsamych z dziełem, w których sztuka nie była jedynie sztucznie zaszczepionym, „odświętnym” elementem. „MIEJSCE jako fakt artystyczny musi - jak czytamy w dokumencie - zaznaczyć się na zewnątrz, musi zobiektyzować się w świecie, a równocześnie miejsce istnieje o tyle, o ile zdoła się

stop (1960) został uznany za pierwszy polski happening muzyczny - K. Pleśniarowicz, Kantor. Artysta końca wieku, Seria „A oto Polska właśnie”, Wrocław 1997, s. 166.

14 Galeria Foksal PSP, kat., Galeria Foksal PSP, Warszawa IV 1966, s. nlb.

15 W. Borowski, H. Ptaszkowska, M. Tchorek, Wprowadzenie do ogólnej teorii Miejsca, w: Program Galerii Foksal PSP, [ulotka], Galeria Foksal PSP, Warszawa, wiosna 1967, s. nlb; przedruk: Tadeusz Kantor. Z Archiwum Galerii Foksal, oprac. M. Jurkiewicz, J. Mytkowska, A. Przywara, Galeria Foksal SBWA, Fundacja Galerii Foksal, Warszawa 1998, s. 417-420.

16 O I Sympozjum Artystów Plastyków i Naukowców (2-23 VIII 1966 r.) zob. w: A. M. Leśniewska, Puławy 66, Puławy 2006. 
uchronić od nacisku świata, o ile się z nim nie utożsamia [...] W świecie nie istnieje żadna wystarczająca racja MIEJSCA. Racja ta istnieje w artyście. On powołuje MIEJSCE"17. Galeria miała być zatem oddana we władanie artysty, by mogła stać się dla niego, jak własna pracownia, przestrzenią otwartą. Przestrzeń tą definiował więc artysta i czynił to przez swoje dzieło. W tym sensie miejsce (galeria) stawało się dla niego polem nieograniczonych możliwości, wprost przeciwnie do ograniczeń, jakie narzucała formuła wystawy. Krytycy uczestnicząc w pracach związanych $\mathrm{z}$ realizacją takich projektów artystycznych, pragnęli dzielić z artystami owe "ryzyko” towarzyszące tworzeniu.

Sam manifest był więc niewątpliwie wyzwaniem postawionym artystom, na które pierwszy zareagował Tadeusz Kantor. Z jednej strony zarzucił krytykom tworzenie własnego, niezależnego i pozaartystycznego pola działan ${ }^{18}$, z drugiej zaś - zakwestionował ich prawo do wygłaszania manifestów artystycznych, rezerwując je wyłącznie dla artystów ${ }^{19}$. Inni artyści jednakże odpowiedzieli pozytywnie na propozycję Galerii. Wkrótce miały w niej miejsce realizacje wpisujące się w postulaty krytyków prowadzących Foksal. Były to w większości wystawy typu environment, przyczyniające się do identyfikacji Galerii jako „miejsca”, w tym m.in. Pokaz $5 x$ Grzegorza Kowalskiego, Zygmunta Krauze, Henryka Morela i Cezarego Szubartowskiego (1966), Pokaz synkretyczny Włodzimierza Borowskiego (1966), Rzeźby linearne Edwarda Krasińskiego (1966), Environment (1967) i wystawa Henryka Stażewskiego z 1969 roku, Volumes Larsa Englunda (1967), wystawy Zbigniewa Gostomskiego z 1967, 1969, 1972 czy cykl trzech wystaw Otwór, Linia, Przeciagg z 1975 roku autorstwa Kojiego Kamoji.

Wiosną 1967 roku został opublikowany Program Galerii Foksal $P S P ?^{20}$, który był próbą określenia kształtu programowego i dotychczaso-

17 W. Borowski, H. Ptaszkowska, M. Tchorek, Wprowadzenie do ogólnej teorii Miejsca.

18 J. Bogucki, Z powodu Azotów (2), „Współczesność” 1966, nr 20, s. 8.

19 T. Kantor, Anty-wystawa (1963), w: Ambalaże, Galeria Foksal PSP, Warszawa 1976, s. nlb. Publikacja w związku z wystawą ambalaży w Whitechapel Gallery w Londynie; przedruk w: Archiwum, w: Tadeusz Kantor. Z Archiwum, s. 328-329.

20 Program Galerii Foksal PSP [ulotka], Galeria Foksal, Warszawa, 1967, s. nlb. W stopce podano skład Komitetu Galerii Foksal PSP: W. Borowski, Z. Gostomski, 
wych dokonań galerii.Zawierałon Wprowadzenie ogólne do teoriiMiejsca, eseje Eliminacja sztuki w sztuce Wiesława Borowskego, Obraz oznaczony Mariusza Tchorka i tekst Tadeusza Kantora o Pokazie 5x. Odpowiedzią na manifest o Teorii Miejsca była partytura happeningu Linia podziatu Tadeusza Kantora - linię podziału należy robić wszędzie i zawsze $1966^{21}$. Została ona przez Borowskiego i Ptaszkowską przyjęta i realizowana w ich przedsięwzięciach jako rodzaj manifestu programowego ${ }^{22}$.

Wymiana poglądów na temat sposobu funkcjonowania Galerii była w tamtym okresie żywiołowa i emocjonalna - podjęta została kolejna próba ujawnienia prowizorycznego wobec działań artystycznych statusu galerii. W grudniu 1968 roku powstał bowiem następny manifest Co nam się nie podoba w Galerii Foksal PSP ${ }^{23}$. Krytycy, podważając dotychczasowe zasady działania Galerii, napisali, że trzeba: „zdać sobie sprawę, że działa się w ramach NAWYKU! / Wykryć i ujawnić to, co we własnym postępowaniu jest NAWYKIEM. Jesteśmy Galerią, której działalność jest bezinteresowna. / Jesteśmy Galerią, której tu w Polsce nie usprawiedliwia handel obrazami. / Dlaczego więc przyjmujemy strukturę galerii handlowej? Dlaczego imitujemy jej reguły postępowania i małpujemy rytuał? Dlaczego wreszcie przyjmujemy jakiekolwiek reguły postępowania? / [...] / w rezultacie: / Działalność niekonwencjonalna zostaje podporządkowana KONWENCJI. [...] / w roku 1965 kwestionowaliśmy WYSTAWĘ. Postulowaliśmy, żeby „wystawy straciły swój wtórny i neutralny wobec dzieła sztuki charakter i stały się formą aktywną artystycznie". / Obecnie kwestionujemy GALERIĘ - w całej jej dotychczasowej strukturze"24.

T. Kantor, E. Krasiński, R. Owidzki, H. Ptaszkowska, H. Stażewski i M. Tchorek.

21 T. Kantor, Happeningi, „Dialog” 1972, nr 9, s. 84-87; W. Borowski, Kantor, Warszawa 1982, s. 152; Tadeusz Kantor. Metamorfozy. Teksty o latach 1938-1974, wybór i oprac. K. Pleśniarowicz, Kraków 2000, s. 370-372.

22 A. Ptaszkowska, Wspólny czas i Wspólne Miejsce, My i On, My i Oni, My i Ja, Ja i On, (próba rozwarstwienia), w: Tadeusz Kantor. Z Archiwum, s. 440.

23 W. Borowski, A. Ptaszkowska, M. Tchorek, Co nam się nie podoba w Galerii Foksal PSP? [ulotka], Galeria Foksal, Warszawa, I 1969, s. nlb.; przedruk: Tadeusz Kantor. Z Archiwum, s. 421-423. W prasie ukazała się komentarz do programu - (grt), Nowy program na dwulecie Galerii Foksal PSP, „Express Wieczorny” 1968, 28 III.

24 W. Borowski, A. Ptaszkowska, M. Tchorek, Co nam się nie podoba w Galerii Foksal PSP? 
Manifest rozpowszechniany w środowisku artystycznym Galerii wywołał natychmiastową odpowiedź artystów. Dnia 18 stycznia 1969 roku rozpoczął się Assemblage Zimowy ${ }^{25}$, w którym wzięli udział artyści: Jerzy Bereś, Zbigniew Gostomski, Tadeusz Kantor, Edward Krasiński, Maria Stangret, Henryk Stażewski oraz trójka krytyków: Wiesław Borowski, Anka Ptaszkowska, Mariusz Tchorek. Assemblage został zaplanowany jako szereg działań bez wyraźnego początku i końca, bez określonej formy i struktury, bez rutyny wernisaży i prezentowania dzieła zaproszonej publiczności. Każdy artysta prowadził w ramach Assemblage’u niezależną akcję, którą obejmował i porzucał w dowolnie wybranym momencie, działając publicznie bądź w zamknięciu ${ }^{26}$ - jak Maria Stangret w Malowaniu pejzażu i Malowaniu progów ${ }^{27}$ czy Tadeusz Kantor w wystąpieniu Maszyna do pisania z żaglem i sterem. Podczas Assemblage'u odbyła się również akcja $M y$ Was widzimy - przyklejone do szyby galerii autorstwa Tadeusza Rolke fotografie twarzy jej założycieli i artystów: Borowskiego, Gostomskiego, Kantora, Krasińskiego, Ptaszkowskiej, Stangret, Stażewskiego, wyglądające z okna na zewnątrz stały się znakiem wyraźnej identyfikacji wobec i przeciw światu zewnętrznemu ${ }^{28}$.

Miało to być zatem wystąpienie przeciwko usankcjonowanej działalności wystawienniczej, a więc odpowiedź na wątpliwości dotyczące rutyny działań Galerii zawarte w najnowszym manifeście programowym. Co więcej, to zaprzeczenie dotychczasowej formuły przybrało postać radykalną, gdyż działania artystyczne przeniesione także zostały poza przestrzeń fizyczną Galerii. Zabieg ten miał pokazać, iż działania artystów nie muszą odbywać się tylko w Foksalu, a tym samym być ograniczone jego „miejscem”. Aby można było to w pełni zrealizować, podjęte akcje przybrały w dużej większości formę happeningu - czyli

25 Assemblage d'Hiver dans la Galerie Foksal PSP [ulotka w jęz. franc.], publiépar la Galerie Foksal PSP, Varsovie IV 1969, s. nlb.

26 H. Ptaszkowska, Happening $w$ Polsce (3).

27 Więcej o Progach i idei ambalaży, w: A. Dzierżyc-Horniak, Kartki zapisane gestem. Twórczość malarska Marii Stangret-Kantor w latach 1957-2005, Warszawa 2005, s. 69-75.

28 A. Ptaszkowska, Wspólny czas, w: Tadeusz Kantor. Z Archiwum, s. 442. 
działania o charakterze nieprzewidzianym, bez wizji efektu końcowego i celu, jakim było stworzenie dzieła.

Mimo że Assemblage zakrojony został jako długofalowa akcja, aktywność artystów ustała po kilku dniach ${ }^{29}$. Można jednak uznać, iż była to kulminacja współpracy Galerii i artystów. W tych seriach wydarzeń - nieokreślonych żadną ramą, ani czasową, ani przestrzenną, ani również spiętych jako całość konstrukcyjnie, fabularnie czy stylowo - postulaty krytyków zostały w dużej mierze spełnione.

Nie był to jednak koniec fermentu w środowisku artystycznym, zapoczątkowanego przez krytyków i artystów Foksalu. We wrześniu 1969 roku grupa skupiona wokół Galerii podjęła na Sympozjum Złote Grono w Zielonej Górze kolejne wspólne działania. Studenci Kantora - Mieczysław Dymny, Tomasz Wawak i Stanisław Szczepański - przedstawili akcję pt. My nie śpimy ${ }^{30}$. Jej pomysłodawcą był Kantor, który na wiadomość, że studenci „nie mogą spać”, zastanawiając się, co pokazać na wystawie, odpowiedział: „To niech nie śpią!”31. Na sympozjum odbywającym się w atmosferze oficjalnego wydarzenia, akcja artystów, którzy siedzieli trzy doby w łóżkach w holu sali wystawowej, nabrała wymowy niezwykle prowokacyjnej ${ }^{32}$, gdyż słowa „My nie śpimy”, znaczyły: „my tu uważamy”. „Wszyscy coś pokazują - wspominał zdarzenie Ludwiński - na przykład obrazy, a oni nie śpią. Czyli, że wszyscy pokazują obrazy, ale "śpią", a oni "nie śpią"»33. Efekt końcowy tego ostrego ataku na artystyczny establishment, grona jurorów i organizatorów wystaw wzmacniały dodatkowo działania krytyków - Ptaszkowska wygłosiła referat przeciwko krytyce niezaangażowanej, Borowski zaś nieustannie informował uczestników sympozjum o trwaniu akcji „niespania”. Nic więc dziwnego, że zaangażowani w nią artyści i krytycy zastali w czasie uroczystego zamknięcia sympozjum oskarżeni przez organizujące imprezę władze wojewódzkie o polityczną prowokację ${ }^{34}$.

29 Tadeusz Kantor. Z Archiwum, s. 30.

30 Tadeusz Kantor. Z Archiwum, s. 33-36.

31 W. Borowski, Tadeusz Kantor, Warszawa 1982, s. 102.

32 W. Skrodzki, Złote Grono-69, „Współczesność” 1969, nr 11, s. 8.

33 Sztuka zmierza do maksymalnej różnorodności (2000), w: J. Ludwiński, Epoka błękitu, oprac. J. Hanusek, Kraków 2003, s. 294.

34 W. Skrodzki, Złote Grono-69. 
Podczas Sympozjum w Zielonej Górze odbyły się też inne działania artystyczne. Druga Grupa - Lesław i Wacław Jannicy oraz Jacek Stokłosa, przeprowadzili akcję Event, polegającą na kopiowaniu na zamówienie prezentowanych podczas sympozjum dzieł. Działaniom tym towarzyszyła także wystawa malarstwa pt. Krytycy zapraszaja artystów, którą w imieniu krytyków zainicjowała Ptaszkowska.

Działania zaprezentowane w Zielonej Górze zapoczątkowały kolejne „propozycje” programowe środowiska Galerii. W październiku 1969 roku Borowski i Ptaszkowska napisali Nowy Regulamin Galerii Foksal $P S P^{35}$, próbując znów podważyć dotychczasowe zasady funkcjonowania Galerii. Tym razem krytycy zaproponowali przekształcenie instytucji w rodzaj informacyjnego punktu, który miał przyjmować bez selekcji napływające zewsząd informacje i zrzec się swojej uprzywilejowanej funkcji na rzecz bezkrytycznego medium. Propozycja ta wypływała poniekąd z doświadczeń z Assemblage'u Zimowego i akcji My nie śpimy w Zielonej Górze, gdyż była ponowioną, choć na nieco innej zasadzie, próbą przeniesienia działań artystycznych poza uprzywilejowany obszar i kompetencje Galerii. Krytycy pisali bowiem: „ogłaszamy przerwę w działalności Galerii Foksal PSP jako miejsca wystaw, happeningów i manifestacji artystycznych wszelkiego typu. [...] Działajcie więc poza nią tak jak działalibyście tutaj. [...] Galeria bierze na siebie obowiązek informowania o waszych poczynaniach i dokumentowania ich. Na terenie galerii będziemy prowadzić otwarty, publiczny i permanentny seans informacyjny"36. Program ten wpisywał się w ideę Kantorowskiej galerii korespondencyjnej, która pozostawiała Galerii jedynie rolę informacyjną, dokumentacyjną i reklamującą prowadzone poza nią działania artystyczne.

Projekt całkowitego otwarcia Galerii na artystyczne działania poza jej przestrzenią doprowadził jednak do konfliktu, i w konsekwencji do

35 W. Borowski, H. Ptaszkowska, Nowy Regulamin Galerii Foksal PSP [mps, ulotka], Galeria Foksal PSP, Warszawa 1969, nlb. Manifest nie został wtedy wydany drukiem, kopie maszynopisu wysyłano artystom. Opublikowany później: A. Ptaszkowaska, Les experriences de la Galerie Foksal de Varsovie, „Les Letters Françaises” 1970, nr 1370, s. 27-29; w j. polskim w: Tadeusz Kantor. Z Archiwum, s. 385.

36 Cyt. za: A. Ptaszkowska, Wspólny czas i wspólne miejsce w: Tadeusz Kantor. $Z$ Archiwum, s. 451. 
rozpadu grupy Foksal. Od połowy 1970 roku narastał bowiem spór co do sposobu funkcjonowania galerii i metod współpracy $\mathrm{z}$ artystami ${ }^{37}$. Ostatecznie nie doszło do realizacji programu, w efekcie Ptaszkowska odeszła $\mathrm{z}$ galerii ${ }^{38}$, a ze współpracy z Foksalem zrezygnowali na jakiś czas także Stażewski i Krasiński. Racje merytoryczne, które powodowały krytykami i artystami w tym sporze, pozostały istotne w całej późniejszej historii Galerii, wpływając m.in. na ukształtowanie jej jako pola oddawanego do całkowitej dyspozycji artystom.

W 1970 roku na Sympozjum Plastycznym Wrocław '7039 Andrzej Turowski - który dołączył w tym czasie do Galerii - przedstawił projekt Centrum Poszukiwań Artystycznych ${ }^{40}$. W tekście tym przedstawiona została idea utworzenia placówki artystycznej, która w sposób odpowiadający wymaganiom nowych czasów prezentowałaby sztukę najnowszą i „żywo” współpracowałaby z artystami. Nie miała to być instytucja nastawiona na kolekcjonowanie i udostępnianie sztuki nowoczesnej, ani też powielająca nieskuteczne wobec nowej sztuki schematy prezentacji obowiązujące w instytucjach wystawienniczych głównego, oficjalnego nurtu. Centrum Poszukiwań Artystycznych miał być realizowany jako „ośrodek studiów artystycznych i ekspozycji pracy, dokumentacji artystycznej oraz dokumentacji i propagandy nowej sztuki”"11. Projekt zakładał żywą współpracę zespołu krytyków i artystów, z naciskiem na rolę krytyków. Mieli oni bowiem kierować placówką, w tym „służyć artystom i ich twórczości” przez jej popularyzowanie i dokumentowanie, a także wyznaczać i aprobować eksperymentalne poszukiwania artystyczne podejmowane w ramach Centrum. Artyści - jak przypomniała Luiza Nader - „tworzyliby zatem CPA niejako pośrednio - nie tyle kształtując je, co współpracując z nadającym mu charakter zespołem

37 List Tadeusza Kantora do Galerii Foksal, w: Tadeusz Kantor. Z Archiwum, s. 390.

38 A. Ptaszkowska, L'expérience devla Galerie Foksal de Varsovie, „Les Lettres Françaises" 1970, nr 1370, 27 I, s. 27-29.

39 J. Bogucki, Wrocław aktualny, „Współczesność” 1967, nr 16, s. 8.

40 W. Borowski, A. Turowski, Centrum Poszukiwań Artystycznych, w: Sympozjum plastyczne Wrocław '70, red. D. Dziedzic, Z. Makarewicz, Ośrodek Teatru Otwartego „Kalambur”, Wrocław 1983, s. 150-152.

41 L. Nader, Sympozjum Wrocław '70: przestrzeń niemożliwego, „Dyskurs. Zeszyty Naukowo-Artystyczne ASP we Wrocławiu” 2005/2006, nr 3, s. 154. 
krytyków"42. Instytucja miała zatem stanowić z jednej strony miejsce konfrontacji idei i artystów, z drugiej zaś - być swoistym punktem informacyjnym i zarazem archiwum.

Tekst Turowskiego i Borowskiego nawiązywał bezpośrednio do Muzeum Sztuki Aktualnej, czyli projektu Jerzego Ludwińskiego z 1966 roku $^{43}$. Ludwiński przedstawił zresztą na Sympozjum zaktualizowaną wersję swojej wcześniejszej propozycji, pod nazwą Centrum Badań Artystycznych ${ }^{44}$. Programy pokazane i dyskutowane we Wrocławiu były w założeniach dość podobne, choć opierały się na odmiennych wizjach sztuki.Oba, niestety, nie doczekały sięinstytucjonalnej realizacji, mimo panującego na sympozjum powszechnego entuzjazmu wobec tych projektów.

Pewne pomysły i intuicje krytyków zasygnalizowane we Wrocławiu doczekały się jednak rozwinięcia w kolejnych propozycjach teoretycznych wysuwanych przez środowisko Foksalu. Krytycy, badający różne aspekty współpracy Galerii z artystami, podjęli coraz bardziej palący problem dokumentowania twórczości artystów. W sierpniu 1971 roku podczas „wyjazdowej sesji” artystów i krytyków w Kuźnicy na Helu ${ }^{45}$ Wiesław Borowski i Andrzej Turowski przedstawili teksty manifestów Żywe Archiwum $^{46}$ i Dokumentacja ${ }^{47}$, które przeformułowały postulat biura informacyjnego w sytuacji nieograniczonej aktywności twórczej i informacji o niej. Tekst Żywe Archiwum określał idee i ramy organizacyjne nowego sposobu funkcjonowania Galerii, w tym przede wszystkim kwestie dotyczące prezentowania twórczości i gromadzonych dokumen-

42 Ibidem, s. 158.

43 J. Ludwiński, Muzeum Sztuki Aktualnej we Wrocławiu (koncepcja ogólna), 1966; przedruk: Sympozjum Plastyczne Wrocław'70.

44 J. Ludwiński, Centrum Badań Artystycznych, 1971; przedruk: Sympozjum plastyczne Wrocław'70; Aneks do programu Centrum Badań Artystycznych, 1971, mps; Plan realizacyjny Centrum Badań Artystycznych we Wrocławiu na rok 1971 - projekt 1971, mps - informacja w: Bibliografia Jerzego Ludwińskiego (niepetna), w: J. Ludwińki, Epoka błękitu, wybór i red. J. Hanusek, Kraków 2003, s. 309, 310.

45 Tadeusz Kantor. Z Archiwum, s. 46.

46 W. Borowski, A. Turowski, Żywe Archiwum [ulotka], Galeria Foksal PSP, Warszawa VIII 1971, s. nlb; przedruk: Tadeusz Kantor. Z Archiwum, s. 425-426.

47 W. Borowski, A. Turowski, Dokumentacja, Galeria Foksal PSP, Warszawa IX 1971, s. nlb; przedruk: Tadeusz Kantor. Z Archiwum, s. 424. 
tów realizacji artystycznych. Jak pisał Piotr Piotrowski ${ }^{48}$, autorzy tekstu postulowali przyjęcie strategii określającej dzieła w momencie, gdy jest ono „neutralnie aktualne”. Znaczyło to, że jedynym sposobem uniknięcia manipulacji faktu artystycznego - czynionym przez "samych twórców”, „aranżerów pokazów”, „zachłannych odbiorców” - jest uchwycenie go w zawieszeniu między naddaniem a obiorem. „Nadaniem”, czyli momentem, w którym dzieło znajduje się jeszcze pod władzą i presją psychiczną artysty, oraz „odbiorem”, czyli sytuacją, w której fakt artystyczny poddawany jest schematyzującym zabiegom interpretacji. Ten stan "pomiędzy” miał być punktem docelowym działań podejmowanych dla tworzenia "ram dla twórczej aktywności” w ramach Żywego Archiwum. Borowski i Turowski proponowali więc zamiast powierzchownej recepcji sztuki - autoanalizę artystyczną i penetrację struktury działa sztuki, zamiast udostępniania - izolowanie ocalałego w dokumentacji faktu artystycznego. Sam Turowski wspominał po latach, że „W 1971 roku, jakby na przekór pojęciu archiwum jako wszystkiego co martwe, archiwum Galerii Foksal nazwaliśmy »żywym archiwum«. Natomiast odebraliśmy życie nadzwyczaj w tamtych latach popularnej dokumentacji. [...] Wraz z uśmierceniem dokumentacji trzeba było ożywić archiwum jako sposób "przekazu« sztuki, jako miejsce »neutralne«, nieingerujące, a przechowujące to, co powraca, to, co istnieje"49.

Drugi z przedstawionych w Kuźnicy tekstów - Dokumentacja - także dotykał problemu dokumentowania twórczości artystycznej, choć $\mathrm{z}$ innej jeszcze perspektywy. W dokumentacji rozumianej jako powszechny zabieg utrwalania zjawisk efemerycznych i konceptualnych w sztuce krytycy dostrzegali zagrożenie. Było to zagrożenie dominacją takich praktyk nad samym faktem artystycznym. „Stwarzamy iluzję przetrwania idei artystycznych, a w istocie dysponujemy skłębioną magmą bezużytecznych artystycznie i przydatnych komercyjnie śladów"50. Dokumentacja - jak pisali krytycy dalej - była w tym kontekście samo-

48 P. Piotrowski, Dekada. O syndromie lat siedemdziesiątych, kulturze artystycznej, krytyce, sztuce - wybiórczo i selektywnie, Poznań 1991, s. 32-33.

49 Na marginesie idei i praktyki archiwum [dyskusja z udziałem Zofii Kulik, Luizy Nader, Kai Pawełek, Bożeny Czubak, Andrzeja Turowskiego], „Obieg” 2007, nr 1-2 (75-76).

50 W. Borowski, A. Turowski, Dokumentacja, s. nlb. 
reprodukującym się, podatnym na nieograniczone manipulacje, sztucznym przedłużeniem działania artystycznego, które przejmowało formy i „maniery” muzeum i kolekcji, aby niepostrzeżenie stawać się formą dzieła sztuki. Takim wszechpotężnym, ich zdaniem, zabiegom należało się przeciwstawić. Zorganizowane wkrótce pokazy - wystawy Żywego Archiwum - Dokumentacja (1 IX 1971 roku) ${ }^{51}$ stały się więc nie tyle prezentacją dokumentacji, co ujawnieniem sposobów działania instytucji, która przedłuża trwanie $\mathrm{z}$ natury nietrwałego dzieła, jakim były nowe formy wypowiedzi artystycznej: happening, performance, event. W ramach swoistego pokazu artystycznego publiczność mogła się zapoznać z materiałami dokumentującymi działalność Galerii Foksal. W korytarzu prowadzącym do wnętrza Galerii zostały zgromadzone recenzje $\mathrm{z}$ wystaw i notatki prasowe z wypowiedziami krytyków o Foksalu. W sali wystawowej, na stołach, zapakowane w worki foliowe prezentowane były katalogi, zdjęcia, plakaty, zaś na ścianie powieszone były teksty programowe i katalogi Galerii. Całość ekspozycji uzupełniały nagrania magnetofonowe, odtwarzające wypowiedzi założycieli, wyjaśniające m.in. zasady organizacji instytucji oraz pokaz filmów i slajdów. Intencje krytyków oddaje w zupełności komentarz Piotrowskiego: „olbrzymia ilość dokumentów uniemożliwiała ich lekturę. W ten sposób poprzez absurdalizację działań dokumentacyjnych, usiłowano zaprzeczyć ich sensowności i samo obronić to, co stanowiło istotę działań artystycznych - same dzieło, istniejące już poza decyzją artysty i przed

51 Żywe Archiwum - Dokumentacja, kat., Galeria Foksal PSP, Warszawa VIII 1971, s. nlb. Rok wcześniej miały miejsce wystawy tzw. wystawy dokumentacyjne. Pierwsza odbyła się w Lozannie, było to jednocześnie pierwsze wystąpienie galerii za granicą. Następna już wystawa dokumentacyjna odbyła się w samej galerii. Wystawy te były realizowane według scenariusza Kantora, który rozwijał w ten sposób ideę archiwum własnej twórczości. W przypadku wystawy z 1971 r. Żywe Archiwum - Dokumentacja nastąpiło rozejście między problemami nurtującymi krytyków galerii a poszukiwaniami Kantora. Uwagi T. Kantora dotyczące dokumentacji, adresowane do W. Borowskiego i A. Turowskiego, [arch. T. Kantora], niedatowane - prawdopodobnie 1971, druk: Tadeusz Kantor. Z Archiwum, s. 405. Więcej na temat wystaw dokumentacyjnych: A. Dzierżyc-Horniak, Miejsce, archiwum, kolekcja. Teksty teoretyczne i manifesty programowe krytyków z Galerii Foksal w latach 1966-1984, w: Dzieje krytyki artystycznej i myśli o sztuce, Materiały z konferencji naukowej, Toruń, 13-15 VI 2007, red. M. Geron, J. Malinowski, Toruń 2009, s. 435-450. 
zabiegiem krytyka, archiwisty itp." ${ }^{22}$ Galeria, choć głosiła manifesty przeciw dokumentacji, gromadząc całe stosy dokumentów, zorganizowała jednak kompletne publiczne archiwum.

W 1978 roku Borowski i Turowski sformułowali kolejny tekst, prezentując idee Kolekcji ${ }^{53}$. Jak pisali sami krytycy, była to: „idea utworzenia przy Galerii Foksal KOLEKCJI dzieł artystów, z którymi pragniemy pozostać w stałym kontakcie [...] Podejmując ideę Kolekcji odrzucamy przede wszystkim ten motyw, który zazwyczaj sprowadza kolekcje do gromadzenia wartości estetycznych, a także materialnych, które kumulują się i procentują w dziele sztuki [...]. Kolekcja powstała w galerii, a raczej nastaje po galerii, rozsadzając i niwelując jej archetypiczne modele i stosunki miedzy galerią i jej artystą"54. Dokument ten był ostatnim z powstałych od 1966 tekstów teoretycznych Galerii. Działalność Galerii Foksal została bowiem w 1981 roku, z powodu stanu wojennego $\mathrm{w}$ Polsce, $\mathrm{z}$ inicjatywy prowadzących galerię zawieszona na trzy lata. W późniejszym okresie działalność programową w znacznym stopniu ograniczono.

Od samego początku Galeria Foksal opierała się na współpracy krytyków z artystami. Bez wsparcia Stażewskiego i Kantora i zaangażowania kolejnych artystów projektu stworzenia „centrum ekspozycyjnego" nie udałoby się zrealizować. Zasada współdziałania Galerii z artystami była zatem wpisana immanentnie w jej funkcjonowanie. Jak pisał Andrzej Kostołowski, w Foksalu „postawiono sobie za cel skupienie niezbyt szerokiego grona najbardziej twórczych artystów, przy czym jako metodę wartościującą przyjęto [...] subiektywną selektywność zjawisk artystycznych [...]. Owa subiektywna ocena jako wynik wyboru, kontaktu i wniosków prezentacji umożliwiła »foksalowcom« zainicjowanie poszukiwań możliwych tylko w niewielkiej galerii, pozwalającej na określone eksperymenty" ${ }^{55}$. Środowisko Foksalu stanowiło zatem dość

52 P. Piotrowski, Dekada, s. 33.

53 Pierwsze notatki na ten temat pochodzą z 1976 roku, kolejne wersje tekstu z 1978 i 1980 roku - Kolekcja, 1980, mps w Archiwum Galerii Foksal; druk: Tadeusz Kantor. Z Archiwum, s. 427.

54 Ibidem.

55 A. Kostołowski, Sztuka i jej meta-. Teksty z lat 1968-2003, wybór M. A. Potocka, Kraków 2005, s. 28. 
wąską grupę, która jednak nigdy - jak mówił sam Wiesław Borowski ${ }^{56}$ nie była ani grupą formalną, ani grupą zamkniętą. Wynikało to z przyjętej postawy i podejścia do wartości, i oczywiście także z powierzchni Galerii, na której niewiele można było pokazać. Krytycy nie tylko wspomagali artystów w ich poszukiwaniach, i umożliwiali wystawienie oraz ciągłe rozwijanie swoich dążeń. Czerpali również z tego, co zaproponowali im sami artyści. Był to proces wzajemnej stymulacji i przenikania działań, co pokazują wyraźnie manifesty programowe Galerii. Przez cały ten czas Foksal mierzył się ze swoją instytucjonalnością, i jak wspominał po latach Borowski ${ }^{57}$, problem ten od samego początku stawiany był bardzo ostro i często był rozważany przez krytyków. Starali się oni, aby instytucja nie zawładnęła sztuką.

Artyści nawiązywali dialog z krytykami - kolejne realizacje artystyczne stanowiły odpowiedź na podejmowane przez krytyków próby ujawniania prowizorycznego statusu galerii wobec działań artystycznych. Ale to właśnie świadomość ograniczeń i pułapek, jakie napotykała Galeria w swej działalności, i nieustanne podejmowanie ryzyka przez zaprzeczenie jej kolejnym zdobyczom powodowały, że Galeria Foksal stała się podmiotem w dyskusjach artystycznych. Zyskując własną tożsamość, stawiała artystom wyzwania i proponowała wymianę idei. $\mathrm{Ci}$, poprzez bliskość i obecność w Galerii, stali się jej rzeczywistymi współtwórcami i sukcesorami. Organizatorom Galerii nie chodziło bowiem o werbowanie owianych legendą artystów, lecz o wzbogacenie i porównanie doświadczeń, szukanie potwierdzeń dla niepewnych myśli o sztuce. Zarówno krytycy, jak i artyści, potrzebowali takiej orientacji i szerszej wymiany poglądów. Wspólnie zatem stawiali oni pytania zasadnicze o sztukę: czym jest dzieło sztuki i kim jest artysta, poszukując jednocześnie właściwej, praktycznej formuły dla tej galerii, już poza oficjalnym obiegiem kultury. To łączenie refleksji nad sztuką i instytucją stało się zresztą znakiem charakterystycznym dla Foksalu.

Oblicze Galerii zmieniało się szybko, ale konsekwentnie. Działania artystyczne i krytyczne podejmowane w ramach Foksalu cały czas ewa-

56 W. Wierzchowska, Sad nieocenzurowany, czyli 23 wywiady z krytykami sztuki, Łódź 1989, s. 18-19.

57 Ibidem, s. 17. 
luowały. Tak samo zmieniały się wzajemne relacje między Galerią (krytykami) a artystami. Proces ten wpisywał się poszukiwania, charakterystyczne dla przemian sztuki światowej lat 60. i 70., prowadzące do przekraczania granic sztuki i anektowania coraz to nowych obszarów. Mimo że Foksal nie chciał być galerią usytuowaną w centrum, lecz działającą na peryferium głównego nurtu sztuki, wiele z form wypowiedzi artystycznej, realizowanych w ramach i przez Galerię, okazało się pionierskimi na gruncie polskim. W dużej mierze było to właśnie efektem unikalnej współpracy środowiska Galerii. Foksal wśród innych galerii posiada więc własne oblicze, które jest lustrzanym obliczem tego, co udało się krytykom i artystom wspólnie dostrzec w sztuce. 


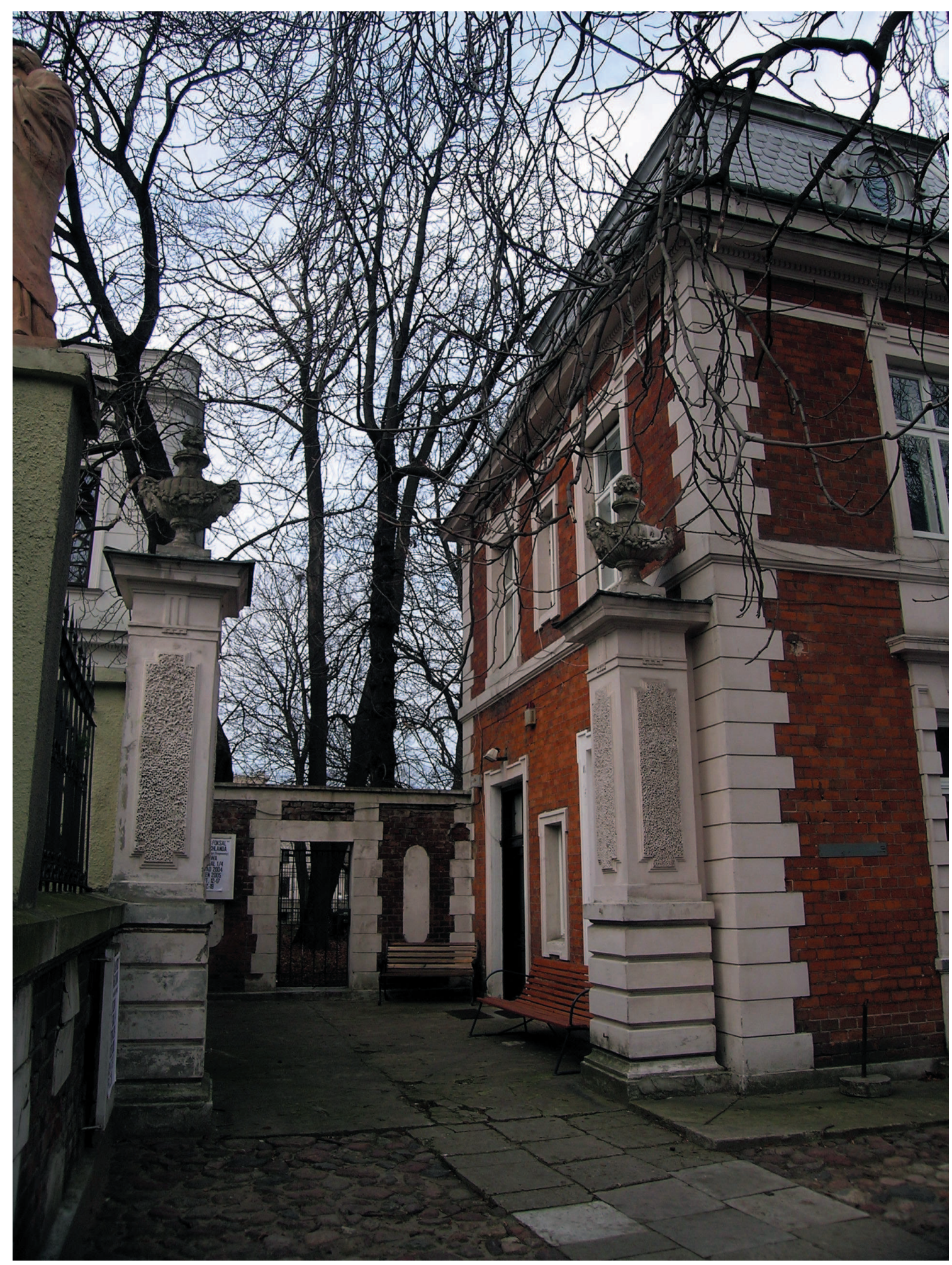

Il. 1. Galeria Foksal - wejście i dziedziniec, Warszawa, jesień 2004 r. (fot. A. Dzierżyc-Horniak) 


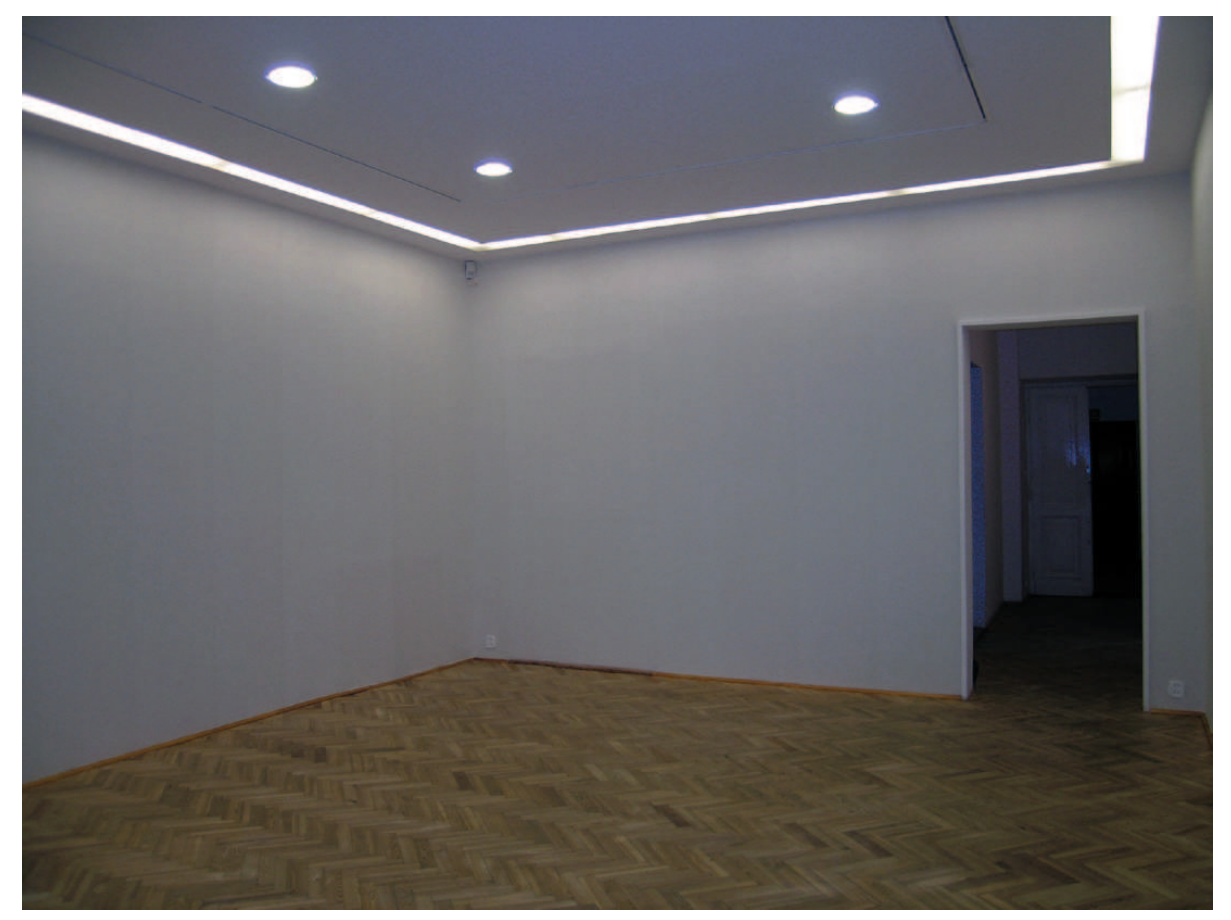

Il. 2. Galeria Foksal - sala wystawowa, październik 2005 r. (fot. A. Dzierżyc-Horniak)

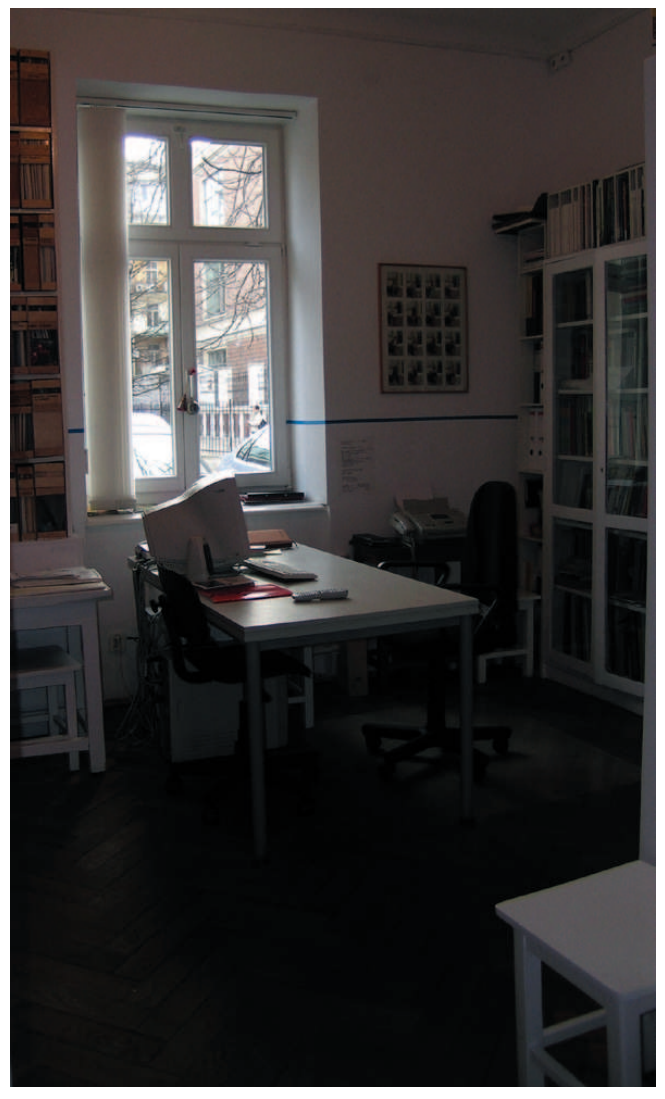

Il. 3. Galeria Foksal - biuro z Archiwum Galerii Foksal, zima 2005 r. (fot. A. Dzierżyc-Horniak) 


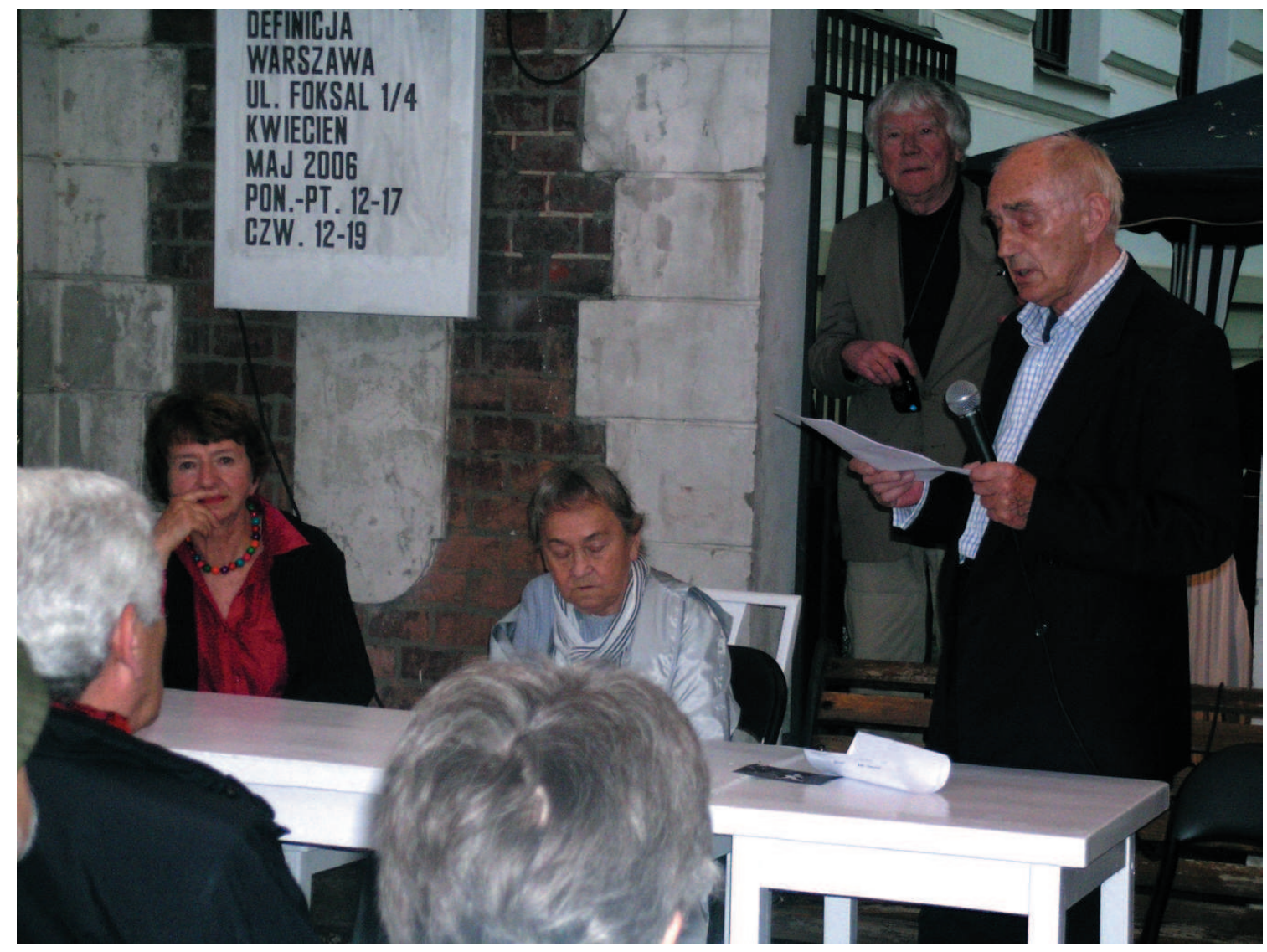

Il. 4. Galerię Foksal współtworzyli krytycy: Wiesław Borowski, Hanna Ptaszkowska i Mariusz Tchorek oraz artyści: Tadeusz Kantor, Henryk Stażewski, Zbigniew Gostomski, Edward Krasiński, Koji Kamoji, Roman Owidzki i Maria Stangret-Kantor. Podczas obchodów związanych z 40-leciem Galerii Foksal, czerwiec 2006 r. Od lewej: Hanna Ptaszkowska, Maria StangretKantor, Tadeusz Rolke (fotograf związany z Galerią), Wiesław Borowski (fot. A. Dzierżyc-Horniak) 


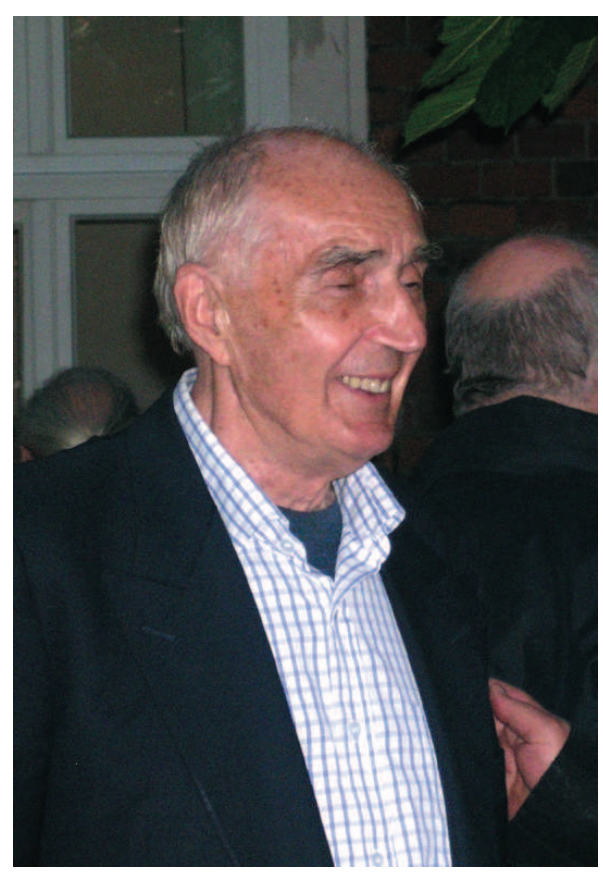

Il. 5. Wiesław Borowski, współzałożyciel i długoletni kierownik Galerii Foksal (do lipca 2006), podczas obchodów 40-lecia Galerii Foksal, Warszawa, czerwiec 2006 r. (fot. A. Dzierżyc-Horniak)

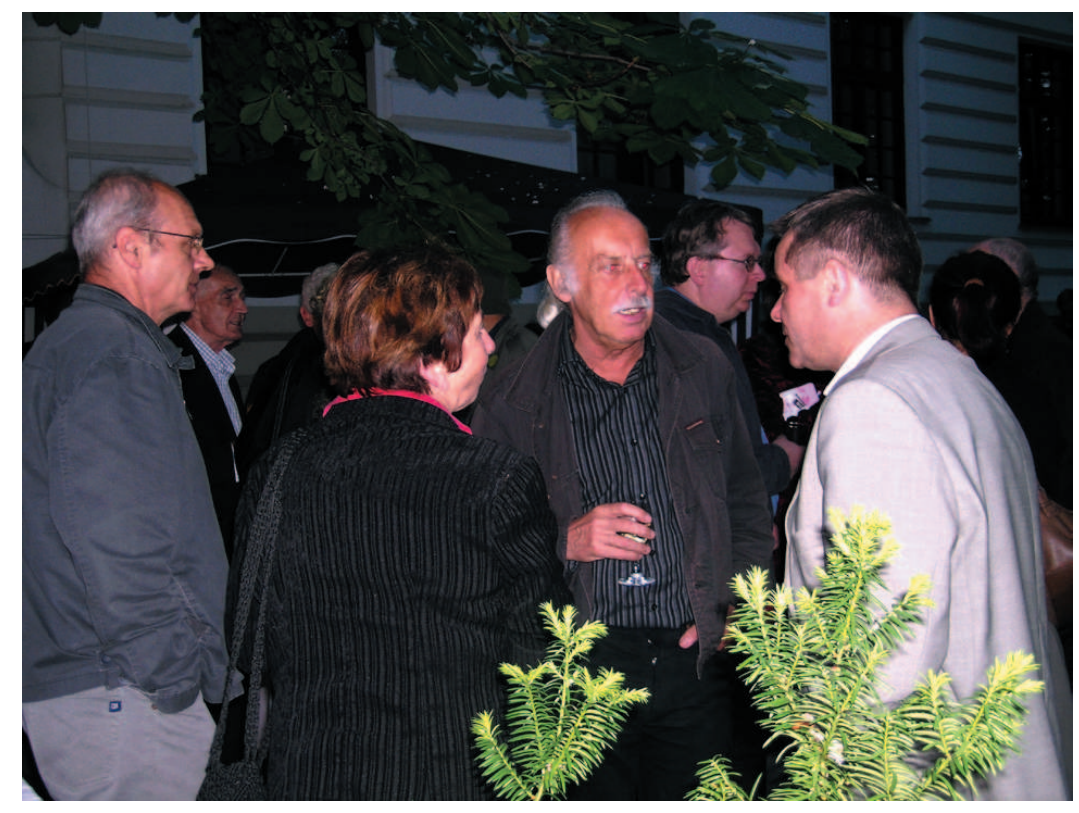

Il. 6. Podczas obchodów 40-lecia Galerii Foksal, Warszawa, czerwiec 2006 r. Od prawej: dr Lech Stangret (obecnie pracujący w Galerii Foksal), Paweł Polit (CSW), prof. Andrzej Turowski (krytyk i teoretyk sztuki, współpracujący z galerią w latach 1971-1983), Hanna Ptaszkowska, Wiesław Borowski (trochę z tyłu), Janusz Głowacki (historyk sztuki, Galeria 86 w Łodzi), fot. A. Dzierżyc-Horniak 


\section{Summary}

\section{Evolution and co-forming - the principle of mutual stimulation between critics and artists in the Foksal Gallery (Gallery programs in the years 1966-1981)}

One of the sources of "success" of the Foksal Gallery was beyond any doubt the functioning formula based on cooperation of artists and critics, who ran the critics' gallery. This process can be apparently seen in the program manifests from 1966-1981, which fulfillment were the artistic activities led in and outside the Gallery. The mentioned cooperation was formed on the experience from the terrains of Lublin - the "Zamek" Group and the "Struktury" magazine (the second half of the 50's), and Warsaw - apprenticeship at M. Bogusz in his Krzywe Koło Gallery (the beginning of the 60's). Critics like W. Borowski, A. Ptaszkowska, M. Tchorek, focused later on such artists like T. Kantor and H. Stażewski, were able to start implementing their project of a gallery. In the text Introduction to a general theory of Place (1966) they declared that the gallery will be given to an artist, so it could become his own workshop, an open space. Exhibitions, such as environment checked in those postulates. In 1968, another manifest was formed - What we do not like about the Foksal PSP Gallery, which was immediately answered by the artists. Winter Assemblage (1969) was planned as a series of actions without any clear beginning and end. In the same year, after the actions taken on the Złote Grono symposium in Zielona Góra, in the New Regulations of Foksal PSP Gallery, there was a suggestion of transforming this institution into a type of information point, which was suppose to accept incoming information without any selection. However, the project led to a conflict and Foksal collapsed. In 1970 on an Art Symposium Wrocław '70, A. Turowski - who joined the Gallery at that time - presented the Centre of Artistic Searches project. The Centre was formed to "serve the artist and their work" in a modern way, by popularizing and documenting it, and simultaneously deter- 
mining experimental searches. In subsequent theoretical propositions - Living Archive and Documentation (1971) - the authors postulated accepting a strategy defining the work of art in a moment, in which it was "neutrally present" and at the same time they were objecting to the domination of the documentation on artistic fact. The soon organized shows became the unmasking of the ways the institution worked - prolonged the lasting of an impermanent work of art, which were the new forms of artistic utterances. After 1981 the program activity of the Gallery was in a considerable degree limited. 